\title{
FARMER'S PERCEPTION OF CLIMATE CHANGE IN THE KOSI - WATERSHED OF CENTRAL HIMALAYAN REGION
}

\section{PAROMITA GHOSH}

G. B. Pant Institute of Himalayan Environment \& Development

Kosi - Katarmal, Almora, Uttarakhand, India

\begin{abstract}
Himalayan ecosystem supports varieties of livelihood options, such as terraced farming, agro forestry and orchards. The main source of rural livelihood and food security in the Indian Himalayan region is, rain-fed agriculture combined with horticulture, agro-forestry and livestock rearing. Climatic change, in temperature and rainfall pattern has drastically affected agriculture, resulting in the poor crop harvest and further disturbing the food security and livelihood opportunities of the Himalayan people.

A study was conducted, along the Kosi watershed at three levels, upper, middle and lower Kosi watershed, to analyze the farmers' perception of climate change. Issues related to agricultural production and their observation of weather changes were recorded through an extensive household survey, with a questionnaire and Participatory Rural Appraisal (PRA) method. The methods adopted by farmers and what they are contemplating, could be a solution to mitigate the climatic problems, were also asked. Four major points discussed were; effect of climate change on soil and water, the impact of climate on agriculture, the general perception of climate change and the impact of climate change on livelihood.

It was concluded from the study that, achieving improved food security in the face of climate change will require: 1. Filling in knowledge gaps about food production systems. 2. Targeting and increasing involvement of younger generations in farming. 3. Supporting greater diversity in small-scale farming. 4. Developing more gender sensitive farming approaches. 5. Strengthening education and building effective networks for knowledge sharing 6. Integrating food security, development goals in policies addressing climate change adaptation and 7. Mainstreaming mountain related issues, in the national discussions on sustainable development goals.
\end{abstract}

KEYWORDS: Farmers' Perception, Central Himalayan Ecosystem \& Climate Change

Received: Sep 21, 2017; Accepted: Oct 15, 2017; Published: Oct 24, 2017; Paper Id: IJASROCT201770

\section{INTRODUCTION}

Himalayan agriculture is facing challenges, due to several factors, such as increased competition for land, water and labour and increasing climate variability. Climate variation is associated with global warming and is likely to result in considerable seasonal and annual fluctuations, in food production. It has been projected by the recent report of the IPCC, and a few other global studies that unless, we adapt there is a probability of $10-40 \%$ loss in crop production in India, by 2080 - 2100, due to global warming (Fischer et al., 2007; Parry et al., 2004; IPCC, 2007). For example, in March 2004, temperatures were higher in the Indo - Gangetic plains, by $3-6^{\circ} \mathrm{C}$ which is almost equivalent to almost $1^{0} \mathrm{C}$ per day, over the whole cropping season. As a result wheat crop matured earlier, by 10 - 20 days and wheat production dropped by more than 4 million tonnes, in the country. Spatio-temporal 
variations in projected changes in temperature and rainfall are likely to lead to differential impacts, in the different regions (Hegde, 2005). There are several special ecosystems, such as our Himalayan ecosystem that are ecologically and economically important, but assessment of impacts on agriculture in these regions, has not received adequate attention.

Farming in the Indian Himalayan Region has been practised from time in memorial and farmers have developed locally suitable practices, to cope with the harsh environment. These farming practices are continuously upgraded to meet new demands, imposed by the continuous and changing local environment. New crop varieties are being introduced to the system. Information on adaptive measures/ practices in a framing system, under the climate change regime from the Himalayan region is fragmentary.

Therefore an on the field assessment study, through PRA and by conducting field workshops, was conducted in the Kosi watershed, to perceive the farmers notion of climate change and what measures they are adopting. The methods adopted by farmers and what they are contemplating could be a solution, to mitigate the climatic problems were also asked. Four major points discussed were an effect of climate change on soil and water, the impact of climate on agriculture, the general perception of climate change and the impact of climate change on livelihood.

\section{MATERIALS AND METHODS}

\section{The Study Area}

The study site was situated in the Kosi watershed, along three altitudinal gradients with a maximum of five spatial point distributions. The river Kosi has its origin in Peenath range, Kausani. Village clusters were selected across the upper, middle and lower ranges. The representative names of villages and their altitude range, is presented in Table 1. Farmers' perception was obtained from the household survey, in the form of rankings and open questions. A total of 200 farmers were also interviewed using structured, pretested and validated interview schedule. Information on the present and past farming practices, starting from land preparation, manuring, sowing, weeding, irrigation and water management, crop maturation, harvesting, thrashing, crop yield and grain storage of various crop varieties were recorded, along with any variation in crop varieties cultivated, along with shifts in sowing and harvesting time. Table 2, provides the crops sown and table 3, describes the present Fasal Chakra, cropping calendar of the region.

\section{RESULTS AND DISCUSSION}

Crop variety, crop management practices and soil fertility levels considerably vary, even from one field to another and also from farmer to farmer. General regional management practices for crops, pests and diseases in the future also will be similar to the current practices. The farmer is assumed to have optimized his variety and will grow the same variety, unless new improved varieties are provided. The farmer's perception of environmental change in Kosi watershed, is presented in table 4 .

\section{Water Status and Farmer Adaptation}

The pooled responses on water status and farmer adaptation, obtained from consultative meeting and PRA is presented, in table 5a. The water crisis is worsening day by day. Both quality and quantity have decreased. Rainfall frequency has decreased, but intensity has increased and rain, during the wrong time like during standing crop or ripening period of crop, is leading to yield losses. It was observed that, more water borne diseases are being reported in villages, than in the past. Loss of Oak and Rhododendron forests, are depleting ground water recharge zone. They are not able to 
take up water based livelihood options.

Some farmers are resorting to roof water harvesting, to fulfil their water requirements. They think large water storage tanks should be built. They want schemes to check and store runoff water and excess water during rains, and proposed more check dams, to be constructed.

\section{Soil Status and Farmer Adaptation}

Soil quality and quantity degradation, due to the rampant use of fertilizers and pesticides, are becoming a major concern. Fertilizers and pesticides tend to lose their potency, after several years of use. It was also observed that, hybrid seeds were more susceptible to disease and showed erratic productivity and yield, compared to local selection. Excess untimely rain is eroding the top soil, leading to massive soil infertility. The pooled responses on soil status and farmer adaptation obtained from consultative meeting and PRA is presented in table $5 \mathrm{~b}$.

Most farmers observed that due to poor soil health, productivity of crops were less so to counter the loss they are taking up value addition of their agricultural products to protect themselves from middle men and get better monetary returns. Some suggested that alternate crops such as millets that are hardy and require less inputs should be given priority.

\section{Forest Status and Farmer Adaptation}

Forest is degrading due to illegal felling of trees and there is a dearth of wild fruits and wild vegetables and wild animals like monkeys and wild pigs are finding it easy to forage and destroy cultivated crops. Lantana an exotic species was the second menace that is leading to forest degradation and loss in agricultural field and affecting fuel and fodder resources. Lantana also supports mosquitoes in their bushy structure and diseases like malaria is also being reported from hills. Many farmers alleged that their forest rights were never given priority and vast tracts of forest were damaged by organized contractors and smugglers. The pooled responses on forest status and farmer adaptation, obtained from consultative meeting and PRA is presented in table 5c.

It was suggested forests, need to be protected at all cost and alternate means of generating electricity, such as micro hydel, solar and wind energy should be adopted, to save fuel wood. Pine litter biobrequettes were known to farmers, but they said, it was not very effective.

\section{Climate Change and Livelihood Options}

The pooled responses to climate change and livelihood options, obtained from consultative meeting and PRA is presented in table 5c. Farmers of all age groups agreed unanimously that, rainfall patterns have changed for the worse. There are more cloud burst events, leading to damage of property and loss of lives. Snowfall has decreased, so there is less recharging of ground water, through percolation of accumulated snow. General temperature has increased in the hills. This temperature is ideal for disease spreading insects, microbes and exotic plants like lantana. Due to more heat work in farms suffer, as people need to stay indoors to ward off the heat. Temperate fruits like Apricots are not growing, to their full yield and tropical trees like Mango and Litchi are surviving better, in the hills due to raised temperatures. Due to drastic changes in climate, livelihood options are decreasing and people are migrating to plains, for better options. Level of education in every stratum was poor and they felt, this was becoming a handicap to compete with the rest of the country and they felt, they were left behind. Farmers expressed their anguish over non implementation of government schemes and they were not given proper subsidies, due to corruption. This was creating a hindrance, in diversifying to alternate means 
of livelihood like medicinal plant cultivation, horticulture, poultry, bee keeping etc.

\section{CONCLUSIONS}

Though, there are many agencies, both government and non government, doing extensive extension work, in the region the farmers felt they still need more support and knowledge, as far as coping climate change is concerned.

Data and learning, gathered from the ground will bring local conservation and development problems forward, providing innovative opportunities. Climate smart agriculture and the landscape approach to agricultural development need to be more firmly included in national adaptation strategies. Both offer practical and complimentary solutions, that will help reduce degradation, alleviate poverty and strengthen food and nutritional security. The impacts are likely to be crop specific and simple adaptation strategies, such as change in variety and altered agronomy, high input delivery and use efficiency can offset the negative impacts of climate change.

Food insecurity has the greatest impact on those people in Himalayan region, who are socially, culturally and economically or otherwise marginalized. Achieving improved food security, in the face of climate change will require:

- $\quad$ Filling in knowledge gaps about food production systems.

- $\quad$ Targeting and increasing involvement of younger generations in farming.

- Supporting greater diversity in small-scale farming.

- Developing more gender sensitive farming approaches.

- Strengthening education and building effective networks for knowledge sharing.

- Integrating food security, development goals in policies addressing climate change adaptation.

- Mainstreaming mountain related issues in the national discussions on sustainable development goals.

\section{ACKNOWLEDGEMENTS}

The author thanks the Director, GBPIHED, for providing the necessary facilities. The study was supported by Ministry of Environment \& Forests and Climate change, Govt. of India through in house funding.

\section{REFERENCES}

1. Fischer, G., Tubielo, F. N., Velthuizen, H. V., Wigerg, D. A. (2007). Climate change impacts on irrigation water requirements: effects of mitigation, 1990-2080. Technol. Forecasting Soc. Change 74, 1083-1107. Doi: 10.1015/j. techfore.2006.05.021.

2. Hedge, D. M. (2005) Oil seed scenario in India-past, present and future with special reference to rapeseed-mustard. In: Winter school advances in rapeseed-Mustard research technology for sustainable production of oilseeds. National centre on rapeseed-Mustard. Sewar, Bhatarpur, December 15 to January 04, 2005. pp. 1-15.

3. Abrar Yousuf, Anil Bhardwaj, A. K. Tiwari \& V. K. Bhatt, Modelling Runoff and Sediment Yield from a Small Forest Watershed in Shivalik Foot-Hills Using WEPP Model, International Journal of Agricultural Science and Research (IJASR), Volume 5, Issue 6, November - December 2015, pp. 67-78

4. IPCC, (2007). In: Parry, M. L., Canziani, O. F., Paultikof, J. P., van der Linden, P. J. Hanon, C. E. (Eds.) Climate chnage impacts, adaptation and vulnerability technical summary of working group II to fourth assessment report of inetrgovernmental panel on climate change. Cambridge University press, Cambridge, UK. pp. 23-78. 
5. Parry, M. L., Rosenzweig. C., Iglesias, Livermore, A. M., Fischer, G., (2004). Effects of climate change on global food production under SRES emission and socio-economic scenarios. Global Environmental Change14, pp. 53- 67.

Table 1: Study Sites

\begin{tabular}{|c|c|c|c|}
\hline S. No & Name of Village Clusters in Kosi Watershed & $\begin{array}{c}\text { Altitude Range } \\
\text { ( m above Sea Level) }\end{array}$ & $\begin{array}{l}\text { Date of Workshop/ } \\
\text { Interview Period }\end{array}$ \\
\hline 1. & $\begin{array}{l}\text { Upper Kosi } \\
\text { (Kantli, Jalna, Lamgara, Mukteshwar, Basauli) }\end{array}$ & $>1500$ & 25th February 20114 \\
\hline 2. & $\begin{array}{l}\text { Middle Kosi } \\
\text { (Someshwar, Hawalbag, Dhaniya- kote, } \\
\text { Daulaghat, Suyalbari) }\end{array}$ & $800-1500$ & 24th March 2014 \\
\hline 3 & $\begin{array}{l}\text { Lower Kosi } \\
\text { (Dabrasonarl, Betal- ghat, Bakule, Kyari) }\end{array}$ & $330-800$ & 12 July 2014 \\
\hline
\end{tabular}

Table 2: Crops Cultivated in the Kosi Watershed Villages (* Dominant Species, ** Associated Species, \$ Crops Grown in Home Garden)

\begin{tabular}{|c|c|c|c|c|c|}
\hline \multicolumn{3}{|c|}{ Kharif } & \multicolumn{3}{|c|}{ Rabi } \\
\hline Common names & $\begin{array}{l}\text { Scientific } \\
\text { Names }\end{array}$ & Local Names & $\begin{array}{c}\text { Common } \\
\text { Names }\end{array}$ & Scientific Names & Local Names \\
\hline Paddy * & Oryza sativa & Dhan & Wheat * & Triticum aestivum & Gehun \\
\hline Finger millet $*$ & $\begin{array}{l}\text { Eleusine } \\
\text { coracana }\end{array}$ & Koda & Oat $* *$ & Avena sativa & Jai \\
\hline Maize \$ & Zea mays & Mungri & Mustard ** & $\begin{array}{l}\text { Brassica } \\
\text { compestris }\end{array}$ & Sarson \\
\hline Amaranth ** & $\begin{array}{l}\text { Amaranthus } \\
\text { frumentaceus }\end{array}$ & Ramdana & Mustard ** & Brassica spp. & Toriya \\
\hline Amaranth ** & $\begin{array}{l}\text { Amaranthus } \\
\text { oleracea }\end{array}$ & Chaulai & $\begin{array}{l}\text { Pigeon pea } \\
* *\end{array}$ & Cajanus cajan & Tor \\
\hline Hemp $* *$ & $\begin{array}{l}\text { Canabis } \\
\text { sativa }\end{array}$ & Bhang & Taro \$ & $\begin{array}{l}\text { Colocasia } \\
\text { antiquorum }\end{array}$ & $\begin{array}{l}\text { Pindalu } \\
\text { Kuchain }\end{array}$ \\
\hline Barnyard millet $* *$ & $\begin{array}{l}\text { Echinochloa } \\
\text { frumentaceae }\end{array}$ & Jhangora & $\begin{array}{l}\text { Soyabean } \\
* *\end{array}$ & Glysine soja & Bhatt \\
\hline Buck wheat $* *$ & $\begin{array}{l}\text { Fagopyrum } \\
\text { esculentum }\end{array}$ & Oggal & $\begin{array}{l}\text { Soyabean } \\
* *\end{array}$ & Glysine spp. & Kala Bhatt \\
\hline Buck wheat ** & $\begin{array}{l}\text { Fagopyrum } \\
\text { tataricum }\end{array}$ & Phapar & $\begin{array}{l}\text { Nacked } \\
\text { barley } * *\end{array}$ & $\begin{array}{l}\text { Hordeum } \\
\text { himalayens }\end{array}$ & $\mathrm{O}-\mathrm{wa}-\mathrm{jau}$ \\
\hline Horsegram $* *$ & $\begin{array}{l}\text { Macrotyloma } \\
\text { uniflorum }\end{array}$ & Gahat & Barley ** & Hordeum vulgare & Jau \\
\hline Kidney bean ** & $\begin{array}{l}\text { Phaseolus } \\
\text { vulgaris }\end{array}$ & Razma & Lentil $* *$ & Lens esculenta & Masoor \\
\hline Sesame ** & $\begin{array}{l}\text { Sesamum } \\
\text { indicum }\end{array}$ & Til & Pea ** & Pisum sativum & Matar \\
\hline
\end{tabular}

Table 3: Annual Crop Calendar (Fasal Chakra), Farming Operations in Villages of Kosi Watershed Kumaon Himalaya

\begin{tabular}{|c|c|c|c|c|c|c|c|c|c|c|c|c|c|}
\hline Months & \multicolumn{13}{|c|}{ Crops } \\
\hline & 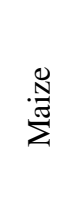 & 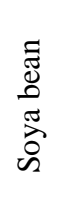 & 莺 & 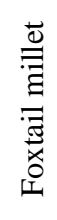 & 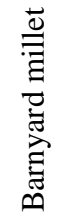 & 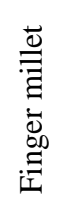 & $\frac{\mathbb{\Xi}}{3}$ & 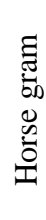 & $\begin{array}{l}\tilde{E} \\
\frac{\pi}{5} \\
\frac{\pi}{\tilde{J}} \\
\frac{\pi}{n}\end{array}$ & $\frac{\vec{E}}{\frac{\vec{d}}{3}} \frac{-}{0}$ & $\frac{\overrightarrow{\tilde{d}}}{\dot{E}}$ & $\underset{\stackrel{D}{\Xi}}{\stackrel{D}{\Xi}}$ & 寻 \\
\hline April-May & $\mathrm{SO}$ & & SO & & & & & & & & & & \\
\hline May - June & WD & & I WD & SO & SO & SO & & & & & & & \\
\hline
\end{tabular}




\begin{tabular}{|c|c|c|c|c|c|c|c|c|c|c|c|c|c|}
\hline \multicolumn{14}{|c|}{ Table 3: Contd., } \\
\hline June - July & & $\mathrm{SO}$ & II WD & & & & & $\mathrm{SO}$ & & & & & \\
\hline July - Aug & & WD & & $\mathrm{TP}$ & $\mathrm{TP}$ & $\mathrm{TP}$ & $\mathrm{SO}$ & WD & $\mathrm{SO}$ & & & & \\
\hline Aug - Sept & $\mathrm{HV}$ & & $\mathrm{HV}$ & WD & WD & WD & WD & & WD & $\mathrm{BD}$ & & SO & \\
\hline Sept - Oct & & $\mathrm{HV}$ & & & & & & & & & & & \\
\hline Oct $-\mathrm{Nov}$ & & & & $\mathrm{HV}$ & $\mathrm{HV}$ & & $\mathrm{HV}$ & & & & LP & $\mathrm{HV}$ & SO \\
\hline Nov - Dec & & & & & & $\mathrm{HV}$ & $\mathrm{HV}$ & $\mathrm{HV}$ & $\mathrm{HV}$ & $\mathrm{HV}$ & SO & & \\
\hline Dec-Jan & & & & & & & & & & & & & \\
\hline Jan - Feb & LP & & & & & & & & & & & & \\
\hline Feb - Mar & LP & & & & & & & & & & & & $\mathrm{HV}$ \\
\hline Mar - April & $\mathrm{SO}$ & & & & & & & & & & $\mathrm{HV}$ & & \\
\hline
\end{tabular}

$\mathrm{LP}=$ land preparation, $\mathrm{TP}=$ transplanting, $\mathrm{BD}=$ broadcasting, $\mathrm{WD}=$ weeding, $\mathrm{SO}=$ sowing, $\mathrm{HV}=$ harvesting.

Table 4: Farmers Perception of Environmental Change in the Kosi Watershed

\begin{tabular}{|c|c|c|c|}
\hline Environmental Aspect & Upper Kosi & Middle Kosi & Lower Kosi \\
\hline Onset of Monsoon & Delayed & Delayed & Delayed \\
\hline Annual precipitation & $\begin{array}{l}\text { Annual amounts } \\
\text { significantly decreased, } \\
\text { decreased rainy days but } \\
\text { increased intensity, erratic } \\
\text { patterns. }\end{array}$ & $\begin{array}{l}\text { Annual } \begin{array}{l}\text { amounts } \\
\text { significantly decreased, }\end{array} \\
\text { decreased rainy days but } \\
\text { increased intensity, erratic } \\
\text { patterns. }\end{array}$ & $\begin{array}{l}\text { Annual amounts } \\
\text { significantly decreased, } \\
\text { decreased rainy days but } \\
\text { increased intensity, erratic } \\
\text { patterns. }\end{array}$ \\
\hline Winter precipitation & Decreased & Decreased & Decreased \\
\hline Weather extremes & $\begin{array}{l}\text { Hot seasons hotter, cold } \\
\text { seasons colder }\end{array}$ & $\begin{array}{l}\text { Hot seasons hotter, cold } \\
\text { seasons colder }\end{array}$ & $\begin{array}{l}\text { Hot seasons hotter, cold } \\
\text { seasons colder, higher } \\
\text { frequency in cold and heat } \\
\text { waves }\end{array}$ \\
\hline Temperatures & $\begin{array}{l}\text { Warmer } \begin{array}{r}\text { temperatures, } \\
\text { slightly to significantly } \\
\text { warmed }\end{array} \\
\end{array}$ & $\begin{array}{l}\text { Warmer } \\
\text { slightly to } \begin{array}{r}\text { significantly } \\
\text { warmed }\end{array}\end{array}$ & $\begin{array}{l}\text { Warmer } \begin{array}{r}\text { temperatures, } \\
\text { slightly to significantly } \\
\text { warmed }\end{array} \\
\end{array}$ \\
\hline $\begin{array}{l}\text { Productivity trend } \\
\text { important crops }\end{array}$ & $\begin{array}{l}\text { Decreases in staple and cash } \\
\text { crops } \quad \text { (exceptions } \\
\text { onion/winter vegetables) }\end{array}$ & $\begin{array}{l}\text { Decrease in major staple and } \\
\text { cash crops }\end{array}$ & $\begin{array}{l}\text { Decrease in staple crop, } \\
\text { increase in cash crops. }\end{array}$ \\
\hline Crop disease and pests & Livestock disease increased & $\begin{array}{l}\text { Livestock disease and insect } \\
\text { attack increased }\end{array}$ & $\begin{array}{l}\text { Livestock disease and crop } \\
\text { pests increased. }\end{array}$ \\
\hline
\end{tabular}

Table 5a: Pooled Responses of Consultative Meeting in Upper, Middle and Lower Kosi Village Clusters on Water Status and Farmer Adaptation

\begin{tabular}{|c|c|c|c|}
\hline S. No. & Issues Identified & $\begin{array}{c}\% \\
\text { Response }\end{array}$ & $\begin{array}{l}\text { Adaptation Approaches to Address } \\
\text { Issues Suggested by Farmers }\end{array}$ \\
\hline 1. & Scarcity of water (potable and irrigation) & 57.1 & \multirow{6}{*}{$\begin{array}{l}\text { Weather forecast information } \\
\text { should be provided. } \\
\text { - New variety seeds requiring } \\
\text { less water be popularized. } \\
\text { - To store water for irrigation } \\
\text { small reservoirs/tanks be supported } \\
\text { financially. } \\
\text { - Govt. schemes for rainwater } \\
\text { harvesting be implemented with more } \\
\text { sincerity. } \\
\text { Check dams for water storage } \\
\text { and irrigation. }\end{array}$} \\
\hline 2. & Irregular monsoon rainfall & 44.4 & \\
\hline 3. & Problems related to water channels for irrigation & 23.9 & \\
\hline 4. & Ground water depletion, natural springs drying & 4.5 & \\
\hline 5. & Drying of other water resources (khaal, gools etc). & 1.4 & \\
\hline 6. & $\begin{array}{l}\text { Increasing landslides due to high intensity rainfall } \\
\text { for short duration, cloud bursts }\end{array}$ & 6.0 & \\
\hline
\end{tabular}


Table 5b: Pooled Responses of Consultative Meeting in Upper, Middle and Lower Kosi Village Clusters on Soil Status and Farmer Adaptation

\begin{tabular}{|c|c|c|c|}
\hline S. No & Issues Identified & \% Response & $\begin{array}{l}\text { Adaptation Approaches to Address Issues } \\
\text { Suggested by Farmers }\end{array}$ \\
\hline 1. & Soil erosion, lack of good agricultural land & 12.3 & \multirow{6}{*}{$\begin{array}{l}\text { - Soil testing be done regularly. } \\
\text { - Use of bio fertilizers, vermin compost } \\
\text { be encouraged and reduce use of inorganic } \\
\text { fertilizers. } \\
\text { - Crop rotation with local crops in } \\
\text { scientific method. } \\
\text { used. Bio pesticides and insecticides be } \\
\text { - } \\
\text { grass and other species on the edges of plots for } \\
\text { reducing soil erosion. }\end{array}$} \\
\hline 2. & Enhanced application of chemical fertilizer & 2.5 & \\
\hline 3. & Deficiency of fertilizers & 7.5 & \\
\hline 4. & Insect and pest infested soil & 5.0 & \\
\hline 5. & Reduced yield & 4.2 & \\
\hline 6. & Declining soil fertility & 55.7 & \\
\hline
\end{tabular}

Table 5c: Pooled Responses of Consultative Meeting in Upper, Middle and Lower Kosi Village Clusters on Forest Status and Farmer Adaptation

\begin{tabular}{|c|c|c|c|}
\hline S. No & Issues Identified & \% Response & $\begin{array}{l}\text { Adaptation Approaches to Address Issues Suggested by } \\
\text { Farmers }\end{array}$ \\
\hline 1. & Reduced forest cover, & 20.4 & \multirow{4}{*}{$\begin{array}{ll}- & \text { Planting fruit trees in jungles. } \\
- & \text { Keeping pet dogs } \\
- & \text { Conservation of broad leaved forests. } \\
- & \text { Massive reforestation and afforestation } \\
- & \text { Electric fencing around agricultural land } \\
- & \text { Eradication of Lantana. } \\
- & \text { Prevent forest fires } \\
- & \text { Popularize alternative energy sources, e.g. solar, wind, } \\
\text { hydro. } & \end{array}$} \\
\hline 2. & Wild animal human conflict & 61.1 & \\
\hline 3. & Forest fires & 2.9 & \\
\hline 4. & Lack of fuel and fodder & 17.5 & \\
\hline
\end{tabular}

Table 5d: Pooled Responses of Consultative Meeting in Upper, Middle and Lower Kosi Village Clusters on Climate Change and Livelihood Options

\begin{tabular}{|c|c|c|c|}
\hline S. No & Issues Identified & $\%$ Response & $\begin{array}{l}\text { Adaptation Approaches to Address } \\
\text { Issues Suggested by Farmers }\end{array}$ \\
\hline 1. & $\begin{array}{l}\text { Unavailability of optimum selling prices of } \\
\text { agricultural products }\end{array}$ & 18.6 & \multirow{11}{*}{ 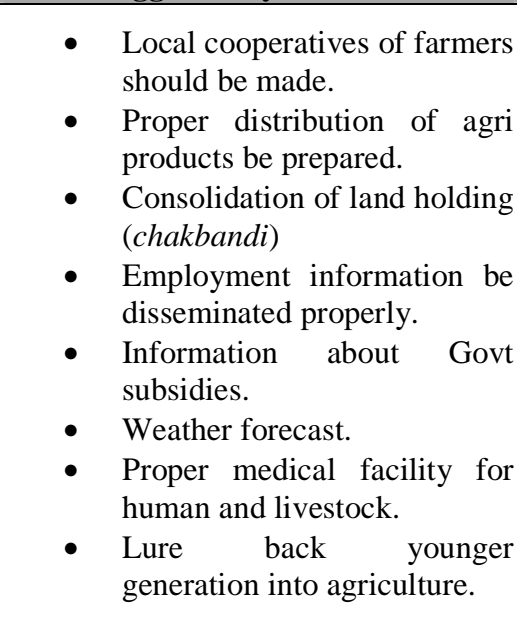 } \\
\hline 2. & Lack of quality seeds and propagules & 2.5 & \\
\hline 3. & Increased crop diseases & 2.9 & \\
\hline 4. & Lack of proper agricultural training & 6.7 & \\
\hline 5. & Out- migration & 26.7 & \\
\hline 6. & $\begin{array}{l}\text { Communication gaps, no proper roads, weather } \\
\text { forecast }\end{array}$ & 25.7 & \\
\hline 7. & Increase in health issues & 30.8 & \\
\hline 8. & Unemployment & 60.0 & \\
\hline 9. & Change in crop rotation due to climate change & 34.5 & \\
\hline 10. & $\begin{array}{l}\text { Reduction in agri-products quality and quantity } \\
\text { due to climate change }\end{array}$ & 58.2 & \\
\hline 11. & $\begin{array}{l}\text { Reduction in winter temperature, high intensity } \\
\text { erratic precipitation, rise in summer temperature } \\
\text { etc. }\end{array}$ & 57.9 & \\
\hline
\end{tabular}


